Vitalija Stravinskienè

Instytut Historii Litwy

(iD) ORCID ID: 0000-0001-6228-3278
OBLICZA WOJNY

TOM $3 \cdot$ MIASTO I WOJNA

ŁóDŹ2021 •ISBN 978-83-8220-556-5 •s. 253-270

https://doi.org/10.18778/8220-556-5.14

\title{
WILNO: STRATY WOJENNE W LATACH 1944-1945
}

Streszczenie. W artykule, na podstawie dokumentów, materiału archiwalnego i historiografii, analizie poddano straty materialne, które spowodował końcowy okres II wojny światowej, czyli walki o Wilno między Armią Czerwoną a Wehrmachtem (lipiec 1944 r.), a także inne czynniki wojenne (wybuch pociągu z amunicją w styczniu 1945 r.). Autor skupia uwagę na zakresie zniszczeń materialnych, mechanizmie ich wykrywania oraz początkowym etapie uporządkowania strat fizycznych. W czasie walk najbardziej zniszczone było Śródmieście i okolice dworca kolejowego. Eksplozja pociągu na dworcu wileńskim na początku 1945 r. jeszcze bardziej powiększyła straty materialne w mieście. Komisja specjalna do spraw szacowania zbrodni nazistów oszacowała straty Wilna w sferze gospodarki i kultury na 1,3 mld rubli.

Słowa kluczowe: Wilno, straty wojenne, komisja ds. oszacowania zbrodni nazistów, eksplozja na stacji kolejowej

II wojna światowa zadecydowała o radykalnych przemianach w historii Wilna. Skutki wojny były bardzo dotkliwie przede wszystkim dla demografii miasta. Wymordowano prawie wszystkich wileńskich Żydów, a mieszkańcy innych narodowości doświadczyli różnorakich represji od kolejnych okupantów. Wilno i jego mieszkańcy ucierpieli również w sferze materialnej. Zrujnowane zostały gmachy, mosty, zakłady przemysłowe (elektrownia, gazownia i inne), domy i mieszkania wilnian. Wiele z tych strat nastąpiło w wyniku bombardowań na początku wojny (1939 i 1941). Jednak zakończenie niemieckiej okupacji nie oznaczało wcale końca wyniszczania miasta. W okresie drugiej okupacji sowieckiej, od lipca 1944 r. do połowy stycznia 1945 r., miasto i ludność doznały nowych, dużych strat materialnych. 
Temat strat materialnych Wilna zarówno pod koniec II wojny światowej, jak i na początku okresu sowieckiego był już tematem badań. Autorzy, którzy analizowali problemy Wilna w czasach sowieckich ${ }^{1}$, pokrótce omówili m.in. straty fizyczne spowodowane działaniami wojennymi, jednak winą za nie w całości obarczyli armię niemiecką. Tematem strat wojennych Wilna zainteresowano się szerzej w ostatnich latach. Najwięcej uwagi poświęcono zniszczeniu Starego Miasta, które rozpoczęło się od ataku Armii Czerwonej, wskutek którego pewnych zniszczeń nie dało się już powstrzymać2. Niektórzy autorzy skupili się na tym, kto bardziej spustoszył Wilno (Niemcy czy Sowieci) ${ }^{3}$, przeanalizowali też inne wydarzenia, które przyczyniły się do wzrostu strat fizycznych ${ }^{4}$. We wspomnianych pracach zabrakowało jednak pełnego obrazu szkód materialnych miasta, ich kalkulacji i likwidacji. Z prac niektórych autorów (Antanas Verkelis) można wywnioskować, że miasto w większym stopniu zostało zniszczone przez Armię Czerwoną. Przy takim podejściu „wkład” wojsk niemieckich w niszczenie zostaje pomniejszony.

W niniejszym artykule zanalizowano szkody materialne Wilna spowodowane działaniami zbrojnymi oraz związaną z działaniem wojska katastrofą na kolei pod koniec II wojny światowej (lipiec 1944 - styczeń 1945), ukazano mechanizm szacowania szkód i początkowy etap ich likwidacji. W celu bardziej obiektywnej oceny strat materialnych Wilna posłużono się nie tylko wspomnianymi wyżej opracowaniami, ale także źródłami archiwalnymi, prze-

${ }^{1}$ H. ŠADŽIUS, Socialistinio Vilniaus darbininkai, Vilnius 1980; Vilniaus miesto istorija, Vilnius 1972.

2 J. MARKeVIČIENÉ, Vilniaus kultūros paveldo apsauga Lietuvos Respublikos (1939-1940), Soviety Sajungos okupacijos bei aneksijos pradžios (1940-1941 ir 1944-1945) ir nacistines Vokietijos okupacijos (1941-1944) laikotarpiu, [w:] Vilniaus kultūrinis gyvenimas 1939-1946, red. A. LAPINSKIENĖ, Vilnius 1999, s. 142-175; M. DRĖMAITĖ, Naujas senas Vilnius: Senamiesčio griovimas ir atstatymas 19441959, [w:] Atrasti Vilnių: skiriama Vladui Dremai, red. G. JANKEVIČıŪTĖ, Vilnius 2010, s. 183-200; M. DrĖMAITĖ, Dingęs 1944-aisiais? Vilniaus miesto sugriovimas ir atstatymas, [w:] Vilnius. 1944 Jano ir Janušo Bulhaku fotografiju archyvas, red. M. MATULYTĖ, Vilnius 2009, s. 27-33; K. KUČIAUSKAS, Profesoriaus Mariano Morelowskio kelias j 1944-uosius: valdžios, kolegos, vertinimai, „Acta Academiae Artium Vilnensis" 2015, nr 77/78, s. 219-240; K. KUČIAUSKAS, Karo padariniॄ vertinimas Vilniaus senamiestyje $1944 \mathrm{~m}$., https://leidiniu.archfondas.lt/alf-05/karolis-kuciauskas-karo-padariniu-vertinimas-vilniaus-senamiestyje-1944-m (dostęp: 10 XII 2020).

3 A. Verkelis, Kas sugriove Vilniu, Vilnius 2015.

${ }^{4}$ M. ĖMUŽIS, Vienos katastrofos istorija: traukinio avarija Vilniuje 1945 m. sausio 12 d., „Naujasis Židinys-Aidai”, 2014, nr 6, s. 34-39; D. PocEVIČıUS, Istoriniai Vilniaus reliktai 1944-1990, d. 1, Vilnius 2018. 
chowywanymi w Litewskim Archiwum Specjalnym oraz Regionalnym Archiwum Państwowym w Wilnie. Zgromadzone tam dokumenty pozwoliły ujawnić mechanizm obliczania szkód materialnych oraz ukazać skutki, jakie dla Wilna i jego mieszkańców miała katastrofy wojenna ze stycznia 1945 r., a które dotąd były całkowicie utajnione. Przydatne były też zbiory lub pojedynczo publikowane dokumenty ${ }^{5}$ oraz artykuły prasowe z omawianego okresu ${ }^{6}$. Cenne źródło stanowią wspomnienia świadków, na podstawie których zrekonstruowano obraz Wilna w drugiej połowie $1944 \mathrm{r}^{7}$

\section{Konsekwencje walk zbrojnych 1944 r. dla Wilna}

Jak już wspomniano, Wilno doznało zniszczeń na początku wojny. Również w 1942 r. nie uniknęło podobnych strat ${ }^{8}$, jednak nie dorównywały one dalszemu fizycznemu jego niszczeniu. Największe straty miasto poniosło pod koniec czerwca i w lipcu 1944 r. Przypomnijmy, że Wilno traktowano jako

5 SSSR w gody Wtoroj mirowoj wojny, t. 2, Vilnius 2012; Lietuvos sovietizavimas 1944-1947 m.: VKP(b) CK dokumentai, Vilnius 2015; Ypatingosios valstybinès komisijos vokiškuju fašistiniu grobiky bei ju bendrininku piktadarybems nustatyti ir ištirti pranešimas apie hitleriniu grobiku nusikaltimus Lietuvos Tarybu Socialistineje Respublikoje, Vilnius 1945.

6 „Tiesa”, „Prawda Wileńska”.

7 M. RÖMER, Dzienniki 1939-1945, t. 6, Warszawa 2018; Biblioteka Akademii Nauk im. Wróblewskich, Dział Rękopisów (dalej: DzR BANW), Dziennik J. Garbėnasa, 1. 1940-1946, z. 8-37; G. LunEVIČIÜTĖ, Vilniaus atminties punktyrai, Vilnius 2020; M. JACKIEWICZ, Wilno wXX wieku. Ludzie i wydarzenia, Bydgoszcz 2013, s. 412-421; H. CZARniawsKi, $W$ Wilnie i okolicach, „Znad Wilii” 2012, nr 50, s. 110-124; J. KRYSZEWSKA, Czy po takich przeżyciach można zapomnieć o Wilnie, „Znad Wilii” 2014, t. 58, s. 100-106; M. ZNAMIEROWSKA-PRÜFFER, Vilnius, miestas arčiausiai širdies, Vilnius 2009; W. ZARZYCKI, Z Wilna do Workuty. Wspomnienia komendanta garnizonu okregu wileńskiego $A K$, Warszawa 2011.

${ }^{8}$ Mieszkająca w Wilnie nastolatka w swoim dzienniku tak pisała o bombardowaniu Wilna 24 III 1942 r.: „Po raz pierwszy odczułam tak wielki, jak dzisiejszej nocy, strach. Bombardowano Wilno. (...) O godzinie dziewiątej [21.00 - V.S.] zobaczyłam, jak rozjaśnił się nasz pokój, po czym dało się słyszeć straszny huk. (...) A tymczasem bomby wciąż spadały i spadały dość blisko naszego domu. Raz tylko błysnęło i uderzyło, szkło i blacha na chodniku dzyń dzyń, potem straszne uderzenie, moim łóżkiem, podobnie jak w innych przypadkach, jedynie wstrząsnęło. Później ucichło. Ale po kilku minutach znowu zbliża się, zbliża i ponownie uderzenie, przerażające. Potem około wpół do jedenastej [22.30 - V.S.] ucichło na dobre” - S. UŽDAVINYTÉ, Dienoraščio fragmentai: Vilnius 1941-1945, Vilnius 2012, s. 33-36. 
miasto-twierdzę, którą Niemcy planowali bronić przy pomocy 79 punktów oporu w jego północnej i południowej części' ${ }^{9}$ Jednak nie udało im się przygotować tylu pozycji obronnych, łącznie zbudowali ich jedynie 12 .

Oddziały wojsk niemieckich stawiały w Wilnie zaciekły opór. Najpierw 6 i 7 lipca 1944 r. odparły atak oddziałów Armii Krajowej od strony wschodniej i południowo-wschodniej. Polskich partyzantów Niemcy ostrzelali za pomocą artylerii i lotnictwa. Prawdopodobnie wtedy ucierpiała zabudowa dzielnicy Antokol. Wkrótce Niemcy musieli podjąć walkę z oddziałami Armii Czerwonej, której oddziały planowały zająć miasto szturmem. Gdy nie udało się zrealizować tego pomysłu, zrealizowano inny plan - Wilno zostało otoczone. Wielokrotnie było bombardowane przez lotnictwo sowieckie: silne ataki miały miejsce 29 czerwca oraz 3, 4 i 7 lipca. Bomby zrzucano w okolicach stacji kolejowej, w centralnej części miasta, w pobliżu ulicy Gerosios Vilties (d. Dobrej Rady) i innych ${ }^{10}$. Miasto ucierpiało w wyniku szturmu lotnictwa, ciężkiej artylerii i czołgów. Intensywne walki trwały przez kilka dni (6-13 lipca), zwłaszcza po 10 lipca. Według ówczesnego mieszkańca miasta, Wilno poniosło duże straty z 11 na 12 lipca, kiedy wieczorem jego zachodnie obrzeże (od Nowego Miasta do Zakretu) ogarnęły płomienie i okrył gęsty gorzki dym ${ }^{11}$.

Do burzenia miasta przyczyniły się też wojska niemieckie - już 7 lipca niemieccy żołnierze wysadzili w powietrze miejską elektrownię, przepompownię wody, kilka mostów (najpierw Zielony, później Antokolski). Wskutek wysadzenia miejskiej stacji wodociągowej zniszczone zostały również pobliskie budynki. W prasie odnotowano, że „Państ. Akademia Sztuk Pięknych w Wilnie (...) musiała wytrzymać wraz z kościołami Bernardyńskim i św. Anny, ciężkie uderzenie z powietrza, gdy Niemcy wysadzali pobliską stację wodociągową. W wyniku tych wszystkich działań Akademia Sztuk Pięknych została bez dachu, stropów, a okna powypadały razem z ramami”"12.

9 P. Stankeras, Mūsiai dèl Vilniaus 1944 metu vasarą, [w:] Vilniaus miesto istorijos skaitiniai, red. E. MANelis, R. SAMAVIČIUS, Vilnius 2001, s. 733.

10 S. LEWANDOWsKa, Życie codzienne Wilna w latach II wojny światowej, Warszawa 1997, s. 305; P. MATEKŪNAS, Okupaciju metai Vilniuje, „Karys” 1989, nr 9, s. 396; Lietuva 1940-1990 metais: okupuotos Lietuvos istorija, Vilnius 2005, s. 263; A. VerkeLIS, op. cit., s. 57.

${ }^{11}$ V.D., Vokiečiai sudegino Vilniaus evangeliku reformatu sinodalinę biblioteka, „Tiesa” 16 IX 1944, s. 5.

${ }_{12}$ M.B., Vilniaus Dailes Akademijoje eina atsatatymo darbai, „Tiesa” 10 VIII 1944, s. 4. 
Miasto doznało poważnych strat, gdy linia frontu przecięła je na pół: od wschodu wkroczyła Armia Czerwona, a w części zachodniej skupiło się wojsko niemieckie, które zostało wyparte z miasta 13 lipca 1944 r. Podczas walk najbardziej ucierpiało Stare i Nowe Miasto, choć zniszczeń nie uniknęły też inne dzielnice - Zwierzyniec, Antokol, Zarzecze. W wyniku walk spłonął luksusowy hotel „Georg”, położony przy stanowiącej przed wojną „serce miasta” ulicy Giedimino (dawniej Mickiewicza) ${ }^{13}$. Ogień ogarnął również budynki położone po drugiej stronie tej samej ulicy ${ }^{14}$. Należy zaznaczyć, że w tej dzielnicy znacznie ucierpiało więcej domów, m.in. położone przy Placu Łukiskim wzdłuż ulicy Vasario 16-osios (dawniej $3 \mathrm{Maja}{ }^{15}$. Teren ten został wybrany jako cel ataków przez pilotów sowieckich ze względu na lokalizację niemieckich instytucji wojskowych (komendant wojskowy, kwatera gestapo). Jedna z głównych ulic miasta - Pylimo (dawniej Zawalna) - również została zbombardowana. Zniszczono tu Kolegium Ewangelicko-Reformowane, kilka budynków gospodarczych ${ }^{16}$. Ucierpiały również sąsiednie ulice: J. Basanavičiaus (dawniej Wielka Pohulanka) i K. Kalinausko (dawniej Mała Pohulanka). Tu uszkodzone zostały domy mieszkalne, cerkiew i Gimnazjum im. Króla Zygmunta Augusta ${ }^{17}$.

Duże straty miasto poniosło w okolicach stacji kolejowej. Mieszkanka jednego z domów, który mniej ucierpiał, tak opowiadała o bombardowaniu w $1944 \mathrm{r}$ :

Któregoś dnia pocisk przeleciał przez całe nasze mieszkanie na czwartym piętrze. Nie wybuchł. Bardzo się baliśmy. Mama wyniosła go na klatkę schodową i włożyła do skrzyni z piaskiem - ten piasek był przeznaczony dla mieszkań na najwyższym piętrze. Przed bombardowaniem mieszkańcy musieli wysypać podłogę piaskiem, aby zmniejszyć ryzyko wybuchu wpadających pocisków. Oczywiście nie mogliśmy już mieszkać w tamtym mieszkaniu - ściana pękła, mieszkanie straciło okna ${ }^{18}$.

13 R. MieczKowski, Kawiarni i restauracje w epoce socjalizmu, „Znad Wilii” 2014, t. 58, s. 118. Należy zaakcentować, że jeszcze bardzo ucierpiało 5 hoteli. Oprócz „Georg”, spalone były „Europa”, "Grand”, „Roma”, „Wenecja”, „Astorja” - F.S., Reorganizacja hoteli wileńskich, „Prawda Wileńska” 24 VIII 1944, s. 2.

14 G. LuneviČIÜTĖ, op. cit., s. 262.

15 A. IVAŠKeVIČIUS, Dingęs Vilnius iš ,apuoko” skrydžio, „Vilniaus diena” 19 IV 2008, https://www. delfi.lt/kultura/naujienos/dinges-vilnius-is-apuoko-skrydzio.d?id=16739750 (dostęp: 24 V 2021).

16 Vilnius. 1944..., s. 242-245.

17 Ibidem.

18 G. LUNEviČIŪTĖ, op. cit., s. 121. 
Jeszcze smutniejszy był los okolic stacji kolejowej od strony zachodniej. Tu wszystko zostało po prostu zmiecione z powierzchni ziemi w połowie stycznia $1945 \mathrm{r}$.

Skutki wojny odczuła w większym stopniu również południowo-zachodnia część dzielnicy Nowe Miasto, w której zniszczone zostały zakłady przemysłowe i domy mieszkalne. Tu między ulicami Mindaugo (dawniej Słowackiego), Naugarduko (dawniej Nowogródzka) i Panerių (dawniej Ponarska) koncentrowały się przedsiębiorstwa (młyny, magazyny $i$ in.), tu także znajdował się najnowocześniejszy przed wojną zakład produkcji odbiorników radiowych Elektrit ${ }^{19}$. Wszystkie te zakłady spłonęły. Według badań autorów litewskich na 525 domów na Starym Mieście 11 zostało zburzonych, 45 - poważnie uszkodzonych i podlegających wyburzeniu, a 125,5 wymagało generalnego remontu ${ }^{20}$.

Szkód nie uniknęła dzielnica Antokol i jej najsłynniejszy obiekt - kościół św. św. Piotra i Pawła. Uszkodzono dach świątyni. Niemcy spalili też szereg domów mieszkalnych. Początkowo nakazali mieszkańcom wyprowadzić się do określonej godziny (właściwie w ciągu dwóch godzin), po czym zaczęli palić budynki. Jeśli znajdowali w nich mieszkańcy, natychmiast ich rozstrzeliwali ${ }^{21}$. W oczach ówczesnego świadka obraz Wilna na początku października 1944 r. wyglądat tak:

Wilno robi smutne wrażenie. W większej części jest w ruinach. Niektóre całe dzielnice albo ulice leżą w gruzach, na przykład ulica Niemiecka albo dzielnica Nowy Świat za koleją. Miejscami są to gruzy, znowuż gdzie indziej sterczą nagie szkielety murów ze spalonym pustym wnętrzem. W innych domach są znów dziury, uszkodzenia lokalne i częściowe. Domów zupełnie zdrowych - mało. Takiego pogromu Wilno nie doznało zupewnie nigdy, może kiedyś, przed setkami lat przy jakichś wielkich pożarach miasta. Wojna obecna, zwłaszcza wypadki lipcowe roku bieżącego, bardzo boleśnie dotknęły Wilno. Wilno było i z armat gruchotane, i bombami z samolotów bite - tak przez Sowietów, jak przez Niemców. Najmniej ucierpiały kościoły wileńskie. Nieuszkodzony też plac katedralny i plac Napoleona za Skopówką [ulica na Starówce - V.S.] i Bonifratrami [kościól św. Krzyża i klasztor w poblisku placa Napoleona - V.S.] oraz piękne stare uliczki między Zamkową a kościołem św. Michała ${ }^{22}$.

\footnotetext{
19 J. STRIUKAS, Ǐ̌ griuvesiu traukiamos mašinos, „Tiesa” 30 VIII 1944, s. 3.

20 J. MARKeViČIenE, op. cit., s. 162; A. Verkelis, op. cit., s. 55, Vilnius 1944, s. $24-25$.

${ }^{21}$ W. ZARZYCKI, op. cit., s. 41, 57.

22 M. ROMER, op. cit., s. 579.
} 
Częściowo zburzone budynki można było oczywiście naprawić lub odbudować. Dla przykładu, mająca szczególne znaczenie dla wileńskich Żydów Wielka Synagoga ucierpiała podczas walk 1944 r. Maria Znamierowska-Prüfferowa, była pracownik Uniwersytetu Stefana Batorego, która odwiedziła ją zaraz po walkach, zastała taki obraz: „Teraz widzimy wokół jedynie gruz i odłamki. Spłonęło główne arcydzieło synagogi - stara galeryjka"23. W takim stanie synagoga pozostawała przez kolejnych kilka lat, aż decyzją władz sowieckich została całkowicie zburzona.

\section{Komisja ds. oceny szkód wojennych i jej działalność}

W celu rejestracji zbrodni hitlerowskich i oceny strat, 13 sierpnia 1944 r. w Litewskiej SRS została powołana „Specjalna państwowa komisja do wykrywania i badania zbrodni niemieckich faszystów i ich współpracowników"24. Komisja ta była integralną częścią komisji działającej w skali całego Związku Radzieckiego. Celem jej powołania były reparacje od Niemiec. Rachunek został wystawiony podczas procesów norymberskich.

Specjalna komisja składała się z najwyższych urzędników partyjnych i przedstawicieli władz administracyjnych LSRS: pierwszego sekretarza KC KPL Antanasa Sniečkusa, przewodniczącego Rady Komisarzy Ludowych LSRS (odpowiednik gabinetu ministrów) Mečislovasa Gedvilasa, komisarza ludowego spraw wewnętrznych LSRS Juozasa Bartašiūnasa oraz przedstawicieli inteligencji, profesorów Antanasa Purenasa i Juozasa Jurginisa. Z centralnej komisji w Moskwie przysłano W. Zurabowa ${ }^{25}$. Jednak jeszcze przed powołaniem komisji wystosowano apel do mieszkańców z prośbą o informowanie o zbrodniach

${ }^{23}$ M. ZnAmierowsKa-PrüfFerowa, op. cit., s. 106.

${ }^{24}$ K. KUČIAUSKAS, Karo padariniu vertinimas Vilniaus senamiestyje 1944 m., https://leidiniu. archfondas.lt/alf-05/karolis-kuciauskas-karo-padariniu-vertinimas-vilniaus-senamiestyje-1944-m\#_ ftn20 (dostęp: 5 XII 2020).

${ }^{25}$ Ypatingosios valstybines komisijos vokiškuju fasistiniu grobiku bei ju bendrininku piktadarybems nustatyti ir istirti pranešimas apie hitleriniu grobikų nusikaltimus Lietuvos Tarybu Socialistineje Respublikoje, „Tiesa” 24 XII 1944, s. 2-4. Sprawozdanie komisji było publikowane w odrębnym wydawnictwie, Ypatingosios valstybinès komisijos vokiškuju fasistiniu grobiku bei ju bendrininku piktadarybems nustatyti ir ištirti pranešimas apie hitleriniu grobiku nusikaltimus Lietuvos Tarybu Socialistinëje Respublikoje, Vilnius 1945, s. 3. 
hitlerowskich przeciwko ludności Litwy (zabójstwach, więzieniu, przymusowym przesiedleniu i in.) i jej mieniu (burzenie obiektów publicznych, niszczenie dóbr kultury $)^{26}$.

Dnia 25 września 1944 r. władze partyjne Wilna utworzyły specjalną komisję, która miała oszacować i odnotować szkody wyrządzone miastu przez nazistów. W jej skład weszło 8 osób na czele z Piotrem Fiodorowiczem, przewodniczącym miejskiego komitetu partyjnego. Członkami komisji byli przedstawiciele różnych instytucji miejskich. Wśród nich znalazł się też polski profesor Kornel Michejda $^{27}$. Wkrótce skład komisji nieznacznie się zmienił ${ }^{28}$.

Komisja ta powołała szereg podkomisji w celu oceny szkód wyrządzonych w poszczególnych sektorach (edukacja, kultura i in.). Te z kolei poleciły swoim podwładnym instytucjom zebranie informacji na temat szkód wyrządzonych różnym obiektom. W ten sposób działały łącznie 292 komisje, które przygotowały 2577 protokołów szkód na mieniu publicznym i prywatnym ${ }^{29}$. Na przykład, szkoda wyrządzona wileńskiemu kościołowi Matki Boskiej Pocieszenia (augustianów) została oszacowana na $1 \mathrm{mln}$ rubli, męskiemu klasztorowi prawosławnemu - 13,5 tys. rubli, Muzeum Sztuki w Wilnie, które mieściło się w Ratuszu - 117 tys. rubli ${ }^{30}$.

Ocenę szkód wyrządzonych budynkom miejskim powierzono Wydziałowi Gospodarki Komunalnej Komitetu Wykonawczego. Jego pracownicy zaczęli obliczać straty, jeszcze zanim specjalna komisja ds. oceny szkód wyrządzonych przez Niemców rozpoczęła swoją pracę. Do połowy sierpnia 1944 r. oszacowali oni, że 733 domy ucierpiały w mniejszym lub większym stopniu: w 100 proc. zniszczono 244 domy, w 75 proc. - 180, w 50 proc. - 59, w 25 proc. - 63, w $10-20$ proc. $-167^{31}$. Prace te były kontynuowane.

Straty wyrządzone wileńskim zabytkom kultury były rejestrowane osobno. Ich oceny dokonała grupa specjalistów pod kierownictwem prof. Mariana Mo-

\footnotetext{
26 O liscie okrucieństw niemieckich, „Prawda Wileńska” 28 VIII 1944, s. 1.

${ }^{27}$ Litewskie Archiwum Specjalne (dalej: LAS), z. 3109, op. 3, t. 1, Protokół posiedzenia komitetu partii w Wilnie z 25 IX 1944 r., k. 1.

${ }^{28}$ LAS, z. 3109, op. 3, t. 1, Protokół posiedzenia komitetu partii w Wilnie z 9 XII 1944 r., k. 35.

29 Vilniaus miesto istorija..., s. 175.

${ }^{30}$ Regionalne Archiwum Państwowe w Wilnie, z. 761, op. 9, t. 6, Akty o stratach kościołów w 1944 r., k. 23-34; V. STRAVINSKIENE், Tarp gimtinès ir Tevvynes: Lietuvos SSR gyventoju repatriacija i Lenkija (1944-1947, 1955-1959 m.), Vilnius 2011, s. 370.

31 Ile domów ulegto zniszczeniu, „Prawda Wileńska” 15 VIII 1944, s. 2.
} 
relowskiego ${ }^{32}$. Ponadto w sierpniu i wrześniu 1944 r. wykonano wizualną dokumentację szkód. Sporządziło ją kilku wynajętych fotografów, w tym słynny wileński artysta fotografik Jan Bułhak i jego syn Janusz. Komisja obliczyła, że straty gospodarki miejskiej i instytucji kulturalnych wyniosły $1 \mathrm{mld}$ $129 \mathrm{mln}$ rubli $^{33}$.

W litewskiej historiografii panuje przekonanie, że w czasie wojny Wilno straciło około 40 proc. przedwojennych budynków mieszkalnych. Skąd się ono wzięło i czy odpowiada rzeczywistej sytuacji? Komisja ds. oceny strat ustaliła, że zniszczonych zostało 3355 domów (20 proc. powierzchni mieszkalnej), zaś częściowo zniszczono 2832 domy (20 proc. powierzchni mieszkalnej) ${ }^{34}$. Przypomnijmy, że na początku 1940 r. szacowano, iż w Wilnie było 13156 domów (3377 murowanych, 9779 drewnianych) ${ }^{35}$. Sumując te liczby, otrzymamy straty powyżej 40 proc. Biorąc pod uwagę cel, dla którego dane zostały zebrane (żądanie odszkodowania od Niemiec), można przyjąć, że nie odpowiadały one rzeczywistej sytuacji i zostały zawyżone. W nowszych pracach autorów litewskich pojawiły się inne liczby. Według A. Verkelisa, w opinii naczelnego architekta Wilna Zygmunta Mieczysława Czaykowskiego, w całym mieście uległo zniszczeniu 1118 domów ${ }^{36}$. Widzimy zatem dużą różnicę między liczbami podanymi przez komisję i architekta miejskiego (2832 a 1118). Wkrótce jednak miastem wstrząsnęła kolejna fala eksplozji, która zniszczyła lub poważnie uszkodziła kolejne 550 domów.

\section{Wypadek na stacji kolejowej 12 stycznia 1945 roku}

Bardzo dużych strat miasto doznało wskutek eksplozji, do jakiej doszło wieczorem 12 stycznia 1945 r. na stacji kolejowej, w wyniku zderzenia się dwóch pociągów $^{37}$. Jeden $z$ nich przewoził amunicję - bomby lotnicze, amunicję

32 Inwentaryzacja zabytków, „Prawda Wileńska” 10 VIII 1944, s. 2.

${ }^{33}$ LAS, z. 3109, op. 3, t. 11, Protokół posiedzenia aktywu partyjnego m. Wilna z 11 i 15 I 1945 r., k. 12.

${ }^{34}$ H. ŠADŽIUS, op. cit., s. 81.

35 Ibidem, s. 80.

36 A. Verkelis, op. cit., s. 56.

37 Podobne katastrofy wojenne miały miejsce również wcześniej. Według świadków, do jednej z nich doszło pod koniec grudnia 1944 r., kiedy na lotnisku w Kirtimai zderzyły się dwa załadowane 
przeciwlotniczą, materiały wybuchowe itp. Fala uderzeniowa spowodowała ogromne szkody w gospodarce miasta: zawaliły się wszystkie budynki w pobliżu miejsca wybuchu, w promieniu od 3 do 4 kilometrów wypadły okna, zostały zerwane tory między stacją główną a stacją ładunkową ${ }^{38}$. W innych źródłach podaje się, że 174 budynki zostały zniszczone całkowicie, a 475 ucierpiało częściowo. Fala uderzeniowa zniszczyła elektrownię, zajezdnię kolejową, zakład produkcji betonu i piekarnię oraz 145 domów mieszkalnych ${ }^{39}$. Inny autor twierdzi, że uszkodzonych od 10 do 100 proc. zostało 105 domów murowanych i 453 drewnianych ${ }^{40}$. Ucierpiało zatem 558 budynków.

Ówcześni świadkowie relacjonowali to wydarzenie różnie. Anonimowy świadek tak oto opisuje sam wybuch i zniszczenia, do których doszło:

Tego styczniowego dnia, około godziny 16, mieszkańcy na już ciemniejącym niebie nad miastem zobaczyli ogromny, przypominający grzyb, słup z płomieni. Sowiecki skład pociągu z pociskami, który jechał na front, wybuchł na dworcu kolejowym. Żadne bombardowanie miasta w czasie wojny nie przyczyniło takich okropnych zniszczeń jak ten wybuch. Cały skład nie wybuchł od razu - przez całą noc dochodziło do pojedynczych wybuchów wagonów, chociaż żołnierze, ginąc, próbowali odciągnąć wagony od epicentrum. Pociąg widocznie wiózł niezwykłą amunicje - ognista wichura bowiem po prostu zmiotła budynek dworca i pobliskie domy. (...) Prawie całe miasto zostało bez okien, fala uderzeniowa wybiła szkła wraz z okiennymi ramami. Szkła z okien lawiną posypały się na przechodniów. Nawet na ulicy Mickiewicza [obecnie - Aleja Giedymina] było mnóstwo rannych. Wileńskie domy, uszkodzone w czasie walk o miasto w lipcu 1944 roku, od mocnej fali uderzeniowej waliły się niby domki z kart. Miasto ucierpiało bardzo mocno ${ }^{41}$.

Jednak taki obraz strat wybuchu był wyolbrzymiony. Największe straty były w okolicach stacji kolejowej. Świadczy o tym relacja innego świadka, który na własme oczy widział skutki wybuchu:

bombami samoloty. Zginęło 6 żołnierzy: H. CZARniaWSKI, $W$ Wilnie i okolicach, „Znad Wilii” 2012, nr 50, s. 120.

${ }^{38}$ Ibidem, s. 121.

39 О. КомягинА, Засекреченная катастрофа. Как взрыв состава из Аиды в 1945-м разрушил Вильнюс больме, чем война, https://news.tut.by/society/537082.html (dostęp: 5 XII 2020).

40 D. POCEvičius, op. cit., s. 269.

${ }^{41}$ B. EAPSZEWICZ, Zapomniana tragedia na dworcu kolejowym, „Kurier Wileński” 8 I 2016, https://kurierwilenski.lt/2016/01/08/zapomniana-tragedia-na-dworcu-kolejowym/ (dostęp: 7 XII 2020). 
Skutki tej katastrofy okazały się tragiczne. Zginęło wielu mieszkańców pobliskich domów, przede wszystkim położonej najbliżej miejsca katastrofy sześciopiętrowej kamienicy. Do rozbiórki jej gruzów zaangażowano m.in. nas - uczniów III Polskiego Gimnazjum Męskiego. W budynku naszej szkoły, znajdującej się w centrum miasta [gimnazjum mieściło się przy ulicy Ostra Brama, niedaleko dworca kolejowego - V.S.], wyleciały wszystkie szyby. O ogromie wyrządzonych szkód mogłem przekonać się osobiście następnego dnia, gdy udałem się do miasta. Kilkaset metrów od stacji leżały koła wagonów wraz z częściami osi. Cały zaś plac przy torach pokryty był warstwą ziemi, pomieszanej z różnymi częściami połamanych mebli itp. Jeszcze nie zdołano usunąć zwęglonych ciał niektórych ofiar, a na zboczu pobliskiej dzielnicy domków jednorodzinnych widniały jedynie ich szkielety ${ }^{42}$.

Ówcześni świadkowie opisywali to wydarzenie różnie. Należy zauważyć, że wypadek ten był utajniony przez wiele dziesięcioleci, większość dokumentów miała najwyższą klauzulę tajności, nie pisała o tym prasa ${ }^{43}$. Udostępnione po 1990 r. historykom litewskie archiwa potwierdzają ogromne straty Wilna i jego mieszkańców, utrwalone we wspomnieniach świadków.

\section{Prace porządkowe i rekonstrukcyjne Wilna}

O odbudowę Wilna dbano na kilku poziomach. Przede wszystkim najwyższa krajowa władza administracyjna, tj. Rada Komisarzy Ludowych (dalej: RKL), poleciła podległemu jej Centralnemu Zarządowi Budowlanemu powołanie specjalnych zrzeszeń organizacji budowlanych. W celu odbudowy Wilna utworzono Trust Budowlany nr $1^{44}$. Prace nad odbudową miasta miał planować i koordynować Zarząd ds. Architektury przy RKL LSRS. Już pod koniec listopada 1944 r. w otoczeniu tego zarządu pojawił się pomysł przygotowania generalnego planu odbudowy Wilna ${ }^{45}$. Jego istotnym elementem była planowa rekonstrukcja miasta, poczynając od centrum (ulic Gedimimo, Didžioji - dawniej Wielka, i Vilniaus - dawniej Wileńska). Na przygotowanie planu przyznano 560 tys. rubli ${ }^{46}$.

${ }^{42}$ H. CZARNIAWSKI, WWilnie i okolicach, „Znad Wilii” 2012, nr 50, s. 122.

${ }^{43}$ Nawet dokumenty najwyższych władz politycznych - litewskiego biura KC KPZR - nie zawierały informacji o tym wypadku, Lietuvos sovietizavimas 1944-1947 m., s. 173.

${ }^{4}$ Atstatymo darbai Vilniuje, „Tiesa” 30 VIII 1944, s. 3.

${ }^{45}$ Gvildenamas generalinis Vilniaus miesto atstatymo planas, „Tiesa” 28 XI 1944, s. 3.

46 J. MANIUŠIS, Atstatysim sostines miesto üki, „Tiesa” 24 II 1945, s. 3. 
Później pojawiły się plany radykalnej przebudowy Wilna. Jeśli chodzi o odbudowę miast Litewskiej SRS (w tym Wilna), autorzy planów podkreślali znaczenie zagospodarowania przestrzennego i ruchu magistralnego ${ }^{47}$. Opis planowanej przebudowy Wilna pojawił się w artykule z 8 kwietnia 1945 r. kierownika Zarządu ds. Architektury RKL LSRS Jonasa Kumpisa, zamieszczonym w głównej krajowej gazecie komunistycznej „Tiesa” („Prawda”). Wynika z niego, że przemysł planowano skoncentrować w dzielnicy Ponary, część ewentualnie pozostawiając na Śnipiszkach, centrum miasta „przesunąć” w kierunku zachodnim, tj. za Górę Bouffałową. Tam miały znajdować się siedziby najważniejszych struktur partyjnych i administracyjnych kraju (KC LPK, RKL, Rada Najwyższa LSRS, Izba Przemysłowa ${ }^{48}$. Wkrótce pojawił się też plan rozwoju stacji kolejowej. Zgodnie z nim stację planowano przebudować i znacznie poszerzyć, ponadto miała stać się "przedpokojem Wilna” ${ }^{49}$.

Prace renowacyjne planowano również na szczeblu władz lokalnych (miejskich). Zakłady komunalne Urzędu Miasta Wilna przygotowały plany odbudowy domów. Według wyliczeń architektów miejskich w przyszłości miało udać się odbudować zaledwie 50 proc. zburzonych budynków. Dla przykładu, w czwartym kwartale 1944 r. na odbudowę przeznaczono 18,3 mln rubli, zaplanowano odbudowę 31 domów, z których większość (23) ucierpiała w mniejszym stopniu ${ }^{50}$.

Polecenie podjęcia w mieście prac porządkowych pojawiło się kilka dni po wkroczeniu Armii Czerwonej. Przewodniczący Miejskiego Komitetu Wykonawczego w pierwszej uchwale z 17 lipca $1944 \mathrm{r}$. nakazał mieszkańcom całkowite oczyszczenie chodników i ulic w pobliżu ich domów ${ }^{51}$. Ze względu na znaczenie, komunikacyjne porządkowanie miasta rozpoczęto od remontu głównych ulic oraz uporządkowania chodników w części centralnej. Pierwszeństwo miały takie ulice jak Gedimino, Pylimo, Žygimantu (dawniej Zygmuntowska) ${ }^{52}$.

${ }^{47}$ Paruošti Lietuvos TSR miestu atstatymo projektai, „Tiesa” 23 XII 1944, s. 3.

48 J. KUMPIS, Sostines Vilniaus atstatymo metmenys, „Tiesa” 8 IV 1945, s. 2; kilka miesięcy później na siedziby organów władz obrano okolice Placu Łukiskiego, „Tiesa” 21 VI 1945, s. 1.

49 Bus praplesta Vilniaus geležinkelio stotis, „Tiesa” 25 V 1945, s. 2; Vilniaus rekonstrukcija, „Tiesa” 21 VI 1945, s. 1.

${ }^{50} 18$ milijonów rubli na odbudowę miasta, „Prawda Wileńska” 5 X 1944, s. 2; V. M. V. K. Butu valdybos namu atstatymo planas 1944 metu IV ketvirčiui, „Tiesa” 28 VIII 1944, s. 4.

${ }^{51}$ RAPW, z.761, op. 9, t. 2, Uchwała nr 1 Komitetu Wykonawczego m. Wilna z 17 VII 1944 r., k. 2.

${ }^{52}$ Biuro budowlane Nr. 1, „Prawda Wileńska” 8 VIII 1944, s. 2; Gruzy znikają, „Prawda Wileńska” 11 VIII 1944, s. 2; Gyvenamuju namy atstatymas, „Tiesa” 21 IV 1945, s. 4. 
W sierpniu 1944 r. remontowano domy, które ucierpiały w mniejszym stopniu, zwłaszcza jeśli lokowały się tam instytucje publiczne. Podpisano wówczas kilkadziesiąt umów z działającymi w mieście przedsiębiorstwami budowlanymi na odbudowę 40 budynków ${ }^{53}$. Jeśli wierzyć statystykom z tamtego okresu, w ciągu 1,5 miesiąca (1 sierpnia - 10 września 1944) naprawiono 16 tys. $\mathrm{m}^{2}$ dachów krytych dachówką oraz 1,1 tys. $\mathrm{m}^{2}$ dachów blaszanych ${ }^{54}$. Warto jednak zaznaczyć, że uporządkowane obiekty użyteczności publicznej (łaźnia, pralnia) służyły przede wszystkim wojsku, a nie mieszkańcom ${ }^{55}$. Można przypuszczać, że część prac budowlanych lub remontowych została wykonana rękami niemieckich jeńców wojennych.

Na łamach prasowych odbudowa Wilna przebiegała oczywiście szybciej niż w rzeczywistości, ta bowiem była znacznie bardziej ponura. Według słów Michaiła Susłowa, „nadzorcy” wysłanego na Litwę z Moskwy, do końca 1944 r. w Wilnie odbudowano zaledwie 37 domów ${ }^{56}$. Źródła archiwalne świadczą o niedogodnościach odczuwanych przez mieszkańców zimą 1944-1945 r. - marzli w mieszkaniach bez szyb, ogrzewania i wody. Jeden z Wilnian wspominał: „Na skutek licznych uszkodzeń miejskiej sieci wodociągowej, często brakowało wody, nie usuwano fekalii. Brak było opału, transportu. Brakowało żywności. Życie w mieście stało się trudne, uciążliwe, a często niebezpieczne z powodu rabunków i napadów uzbrojonych, na nic nie zważających sołdatów" ${ }^{57}$. Podobne wspomnienia mieli też inni mieszkańcy Wilna ${ }^{58}$.

Prace związane z odbudową Wilna przyspieszyły w 1945 r., kiedy z budżetu państwa przyznano na ten cel znaczne środki oraz w odbudowę zaangażowani zostali mieszkańcy miasta i pracownicy instytucji. Z budżetu państwa dla miasta przyznano $35 \mathrm{mln}$ rubli, z czego $20 \mathrm{mln}$ na odbudowę i naprawę zburzonych domów, a 6,5 mln na remont infrastruktury miejskiej i odbudowę przemysłu ${ }^{59}$. Porządkowanie Wilna nabrało tempa wiosną 1945 r., kiedy tysiące mieszkańców przyłączyło się do prac przy usuwaniu gruzów. Pierwsze takie akcje miały

53 Atstatymo darbai Vilniuje, „Tiesa” 30 VIII 1944, s. 3.

54 Vilniaus kronika, „Tiesa” 16 IX 1944, s. 6.

55 B. LeONAS-PUŠINIS, Vilnius tvarkomas ir gražinamas, „Tiesa” 11 VIII 1944, s. 1; Iš Vilniaus Miesto Vykdomojo Komiteto veiklos, „Tiesa” 14 VIII 1944, s. 2.

${ }^{56}$ Lietuvos sovietizavimas 1944-1947 m., s. 163.

57 M. JACKIEWICZ, op. cit., s. 421.

${ }^{58}$ LAS, z. K-1, op. 10, t. 10, Specjalne zawiadowienie dla pierwszego sekretarza Centralnego Komitetu partii Litwy z 2 XII 1944 r., k. 62.

59 Lietuvos TSR sostines atstatymui skiriama 35 milijonai rubliu, „Tiesa” 23 XII 1944, s. 2. 
miejsce już w drugiej połowie sierpnia 1944 r. Na przykład, 20 sierpnia 1944 r. porządkowali okolice stacji kolejowej, pracownicy elektrowni wileńskiej - elektrownię położoną po drugiej stronie Wilii ${ }^{60}$. Praktycznie każde miejskie przedsiębiorstwo czy instytucja musiały wysyłać swoich pracowników do usuwania gruzów w czasie wolnym od pracy.

Oprócz robotników w odgruzowywanie zaangażowani byli studenci i uczniowie. Tak jeden opowiadał o doświadczeniach kolegi:

Jako że Nikita przeprowadził się do Wilna wkrótce po wojnie, kiedy nadal było ono poważnie zniszczone, opowiedział, jak przyczynił się do odbudowy miasta: Wydano rozkaz: każdy mieszkaniec Wilna, w tym uczniowie klas dziewiątych i wyższych, musi przepracować 100 godzin $^{61}$ przy odbudowie miasta. Do rąk nosze, rękawiczki ${ }^{62}$, i idziemy. Szliśmy na ruiny, układaliśmy resztki cegieł starannie w stosy, starannie [układaliśmy] je na samochody. Tak pracowaliśmy, myślę, że jest to bardzo potrzebna i zdrowa rzecz - że tak powiem, przyczyniliśmy się swoją pracą do odbudowy Wilna ${ }^{63}$.

Za taką pracę nie wypłacano żadnego wynagrodzenia. Masowe weekendowe (niedzielne) odgruzowywanie gromadziło dziesiątki tysięcy mieszkańców. 27 maja 1945 r. miasto porządkowało 20 tys. osób, 10 czerwca - około 14 tys. ${ }^{64}$ Usuwanie gruzów odbywało się też wieczorami (w godz. 18.00-21.00). Podobna praktyka porządkowania miasta obowiązywała przez kilka kolejnych lat. Obiektywnie rzecz ujmując, miała ona charakter bardziej przymusowy, czasami wymagano, by ta sama osoba pracowała kilkakrotnie. Miało to miejsce wówczas, gdy osoba jako pracownik konkretnej instytucji musiała porządkować miasto wraz ze swoimi współpracownikami, a później, jako członek mniejszej jednostki organizacyjnej tej instytucji (np. związku zawodowego), musiała ponownie usuwać gruz lub wykonywać inną pracę. Odbudowa Wilna znacznie przyspieszyła, gdy w 1948 r. przyjęto w tej sprawie uchwałę Rady Ministrów ZSRS.

60 Sekmadienio talka prie Vilniaus elektrines atstatymo darbu, „Tiesa” 21 VIII 1944, s. 4; Pierwszy „niedzielnik” w Wilnie, „Prawda Wileńska” 22 VIII 1944, s. 2.

$61 \mathrm{Z}$ innych źródeł wiadomo, że obowiązywało od 16 (osoby pracujące) do 32 (osoby bezrobotne) godzin pracy miesięcznie. H. ŠADŽIUS, op. cit., s. 88.

62 Inni uczestnicy takich akcji nie wspominali o odzieży roboczej i rękawiczkach.

63 M. LuKOŠIENĖ, Gyvene pokario Vilniuje atskleidè jaudinančias patirtis: maista laike tarp langu, https://www.lrytas.lt/bendraukime/reporteris/2020/01/01/news/gyvene-pokario-vilniuje-atskleidejaudinancias-savo-patirtis-maista-laike-tarp-langu-13101561/(dostęp: 8 XII 2020).

${ }^{64}$ H. ŠADŽIUS, op. cit, s. 88. 


\section{Wnioski}

Wilno dość mocno ucierpiało w lipcu 1944 r., kiedy Armia Czerwona zaatakowała miasto z marszu. Ponieważ Wilno było miastem-twierdzą, sowiecki plan się nie powiódł, dlatego zostało otoczone. Do pokonania armii niemieckiej wykorzystano lotnictwo i ciężką artylerię, powodując znaczne szkody w gospodarce miejskiej. Najbardziej ucierpiały strategiczne obiekty Wilna: lotnisko w Kirtimai (dawniej Porubanek) wraz z terminalem obsługi pasażerów, stacja kolejowa, obiekty inżynieryjne (3 mosty na Wilii), zakłady przemysłowe i infrastruktura miejska (gazownia, pompownia wody), instytucje kultury (biblioteki, centra badań naukowych). Do zniszczenia miasta przyczyniły się zarówno Armia Czerwona, jak i Wehrmacht.

W tym czasie szczególnie duże straty poniosło dziedzictwo żydowskie w Wilnie, które koncentrowało się na Starym i Nowym Mieście. Zostały zbombardowane i spłonęły synagogi, szkoły, biblioteki, Żydowski Instytut Naukowy, inne placówki publiczne i prywatne. Inne wspólnoty wyznaniowe Wilna, zwłaszcza ewangelicko-reformowana, również poniosły znaczne straty - straciły bezcenną bibliotekę synodalną ze wszystkimi książkami i rękopisami. Ówczesna mieszkanka Wilna zauważyła: „Za mną pozostawało moje miasto, ostrzeliwane coraz gwałtowniej. W wielu miejscach już wybuchały pożary i z daleka był widoczny ogień i kłębiące się dymy. Co chwila następował silniejszy wstrząs jakiegoś wybuchu. Patrzyłam z przerażeniem na walczące Wilno, z poczuciem, że uciekam, gdy ono ginie, że go nie będzie, przestanie istnieć" 65 . Jej obserwacja okazała się prorocza, gdyż przestały istnieć całe dzielnice miasta, które kształtowały się przez wiele stuleci, pozostały jedynie zapisane w dokumentach historycznych i w pamięci mieszkańców.

Kolejny etap niszczenia miasta był wynikiem zaniedbań sowieckich urzędników. Wskutek tego 12 stycznia 1945 r. na stacji kolejowej w Wilnie doszło do katastrofy pociągu z amunicją wojskową. Seria eksplozji zmiotła zabudowania położone najbliżej (całkowicie zniszczonych zostało 140 domów), uszkodziła położony w odległości $800 \mathrm{~m}$ dawny główny budynek dworca, zginęło ponad 100 osób.

${ }^{65}$ J. KRYSZEWSKA, Czy po takich przeżyciach można zapomnieć o Wilnie, „Znad Wilii” 2014, t. 58, s. $103-104$. 
Do oszacowania szkód, jakich doznało Wilno, powołano specjalne komisje, które obliczyły, że straty fizyczne wyrządzone gospodarce miejskiej i kulturze wynoszą $1 \mathrm{mld} 129 \mathrm{mln}$ rubli. Porządkowanie i odbudowę Wilna rozpoczęto już latem 1944 r., prace przyspieszyły w 1945 r. Przymusowo zostało w nie zaangażowanych wiele tysięcy wilnian, którzy za darmo musieli usuwać gruz, sprzątać ulice, chodniki i wykonywać inne prace.

\section{BIBLIOGRAFIA}

\section{Źródła archiwalne}

Biblioteka Akademii Nauk im. Wróblewskich

Dział Rękopisów, z. 837.

Litewskie Archiwum Specjalne

z. 3109, op. 3, t. 1; z. 3109, op. 3, t. 11; z. K-1, op. 10, t. 10.

Regionalne Archiwum Państwowe w Wilnie

z. 761, op. 9, t. 2; z. 761, op. 9, t. 6.

\section{Źródła drukowane}

Lietuvos sovietizavimas 1944-1947 m.: VKP(b) CK dokumentai, Vilnius 2015.

SSSR w gody Wtoroj mirowoj wojny, t. 2, Vilnius 2012.

Ypatingosios valstybines komisijos vokiškuju fašistiniu grobiku bei ju bendrininku piktadarybems nustatyti ir ištirti pranešimas apie hitleriniu grobiku nusikaltimus Lietuvos Tarybu Socialistineje Respublikoje, Vilnius 1945.

\section{Prasa}

„Prawda Wileńska” 1944.

„Tiesa” 1944, 1945. 


\section{Opracowania}

Czarniawski H., W Wilnie i okolicach, „Znad Wilii” 2012, nr 50, s. 110-124.

Drèmaitè M., Dingęs 1944-aisiais? Vilniaus miesto sugriovimas ir atstatymas, [w:] Vilnius. 1944 Jano ir Januso Bulhaku fotografiju archyvas, red. M. Matulyte, Vilnius 2009, s. 27-33.

Drèmaitè M., Naujas senas Vilnius: Senamiesčio griovimas ir atstatymas 1944-1959, [w:] Atrasti Vilniu: skiriama Vladui Dremai, red. G. Jankevičiūtè, Vilnius 2010, s. 183-200.

$\dot{E}$ mužis M., Vienos katastrofos istorija: traukinio avarija Vilniuje $1945 \mathrm{~m}$. sausio 12 d., „Naujasis Židinys-Aidai” 2014, nr 6, s. 34-39.

Jackiewicz M., Wilno w XX wieku. Ludzie i wydarzenia, Bydgoszcz 2013.

Kryszewska J., Czy po takich przeżyciach można zapomnieć o Wilnie, „Znad Wilii” 2014, t. 58, s. 100-106.

Kučiauskas K., Profesoriaus Mariano Morelowskio kelias i 1944-uosius: valdžios, kolegos, vertinimai, „Acta Academiae Artium Vilnensis” 2015, nr 77/78, s. 219-240.

Lewandowska S., Życie codzienne Wilna w latch II wojny światowej, Warszawa 1997.

Lietuva 1940-1990 metais: okupuotos Lietuvos istorija, Vilnius 2005.

Lunevičiūtė G., Vilniaus atminties punktyrai, Vilnius 2020.

Markevičienè J., Vilniaus kultūros paveldo apsauga Lietuvos Respublikos (1939-1940), Soviety Sajungos okupacijos bei aneksijos pradžios (1940-1941 ir 1944-1945) ir nacistines Vokietijos okupacijos (1941-1944) laikotarpiu, [w:] Vilniaus kultürinis gyvenimas 1939-1946, red. A. Lapinskiené, Vilnius 1999, s. 142-175.

Matekūnas P., Okupacijų metai Vilniuje, „Karys” 1989, nr 9, s. 393-398, 424.

Mieczkowski R., Kawiarni i restauracje $w$ epoce socjalizmu, „Znad Wilii” 2014, t. 58, s. $115-128$.

Pocevičius D., Istoriniai Vilniaus reliktai 1944-1990, d. 1, Vilnius 2018.

Römer M., Dzienniki 1939-1945, t. 6, Warszawa 2018.

Stankeras P., Mūšiai dèl Vilniaus 1944 metu vasarą, [w:] Vilniaus miesto istorijos skaitiniai, red. E. Manelis, R. Samavičius, Vilnius 2001, s. 732-735.

Stravinskienè V., Tarp gimtines ir Tévynes: Lietuvos SSR gyventoju repatriacija i Lenkija (1944-1947, 1955-1959m.), Vilnius 2011.

Šadžius H., Socialistinio Vilniaus darbininkai, Vilnius 1980.

Uždavinytė S., Dienoraščio fragmentai: Vilnius 1941-1945, Vilnius 2012.

Verkelis A., Kas sugriove Vilniu, Vilnius 2015.

Vilniaus miesto istorija, Vilnius 1972.

Zarzycki W., Z Wilna do Workuty. Wspomnienia komendanta garnizonu okregu wileńskiego AK, Warszawa 2011.

Znamierowska-Prüffer M., Vilnius, miestas arčiausiai širdies, Vilnius 2009. 


\section{Netografia}

Ivaškevičius A., Dingęs Vilnius iš „apuoko” skrydžio, „Vilniaus diena”, 19 kwietnia 2008, https://www.delfi.lt/kultura/naujienos/dinges-vilnius-is-apuoko-skrydzio. d?id=16739750 (dostęp: 24 V 2021).

Kučiauskas K., Karo padariniu vertinimas Vilniaus senamiestyje 1944 m., https://leidiniu. archfondas.lt/alf-05/karolis-kuciauskas-karo-padariniu-vertinimas-vilniaus-senamiestyje-1944-m\#_ftn20 (dostęp: 5 XII 2020).

Lukošienè M., Gyvene pokario Vilniuje atskleide jaudinančias patirtis: maista laike tarp langu, https://www.lrytas.lt/bendraukime/reporteris/2020/01/01/news/gyvenepokario-vilniuje-atskleide-jaudinancias-savo-patirtis-maista-laike-tarplangu-13101561/ (dostęp: 8 XII 2020).

Łapszewicz B., Zapomniana tragedia na dworcu kolejowym, „Kurier Wileński”, 8 I 2016, https://kurierwilenski.lt/2016/01/08/zapomniana-tragedia-na-dworcu-kolejowym/ (dostęp: 7 XII 2020).

Комягина О., Засекреченная катастрофа. Как взрьв состава из Аидь в 1945-м разрушил Вильнюс больше, чем война (Komyagina O., Zasekrechennaya katastrofa. Kak vzryv sostava iz Lidy v 1945-m razrushil Vil'nyus bol'she, chem voyna), https://news.tut. by/society/537082.html (dostęp: 5 XII 2020).

\section{Vitalija Stravinskienè}

\section{VILNIUS: WAR LOSSES IN THE YEARS 1944-1945}

Summary. The article, based on collections of documents, archival materials and historiography, discusses the material losses caused to the city of Vilnius by the war battles in 1944 and railway explosion in 1945. The author focuses on the scope of material damage, the mechanism of their detection and the initial stage of setting the physical losses. The centre part of the city suffered the most during the combats, but the explosion of the train ammunition at the beginning of 1945 increased the material losses even further. The special commission to determine the physical losses estimated that the damage to the city's economy and culture amounted to 1 billion 129 million rubles.

Keywords: Vilnius, scope of material damage, the special commission to determine the physical damage, railway explosion 